\title{
Algal comparative floristic of the Alakol Lake Natural State Reserve and other lakes in Kazakhstan
}

\begin{abstract}
Comparative floristic analysis was doing for the new data about algal diversity of the Alakol Lake and 42 algal floras of the Kazakhstan lakes studied by us earlier in purpose to reveal major environmental factors that influenced algal floras forming process in arid region of Eurasia. Algal diversity was studied in first time during 2015- 2017. We revealed 208 taxa of species and infraspecies level from five taxonomic Divisions. Diatom algae were prevailing in species richness of all studied areas communities excluding charophyte communities in the northern part of the lake. In present level of the Kazakhstan lakes floras study, the Alakol Lake flora is one of ten richest, and therefore can be included to the Kazakhstan floras analysis. Comparative floristic analysis with statistical programs helps us to reveal that floristic tree of similarity is better to use for the lake size and salinity class relation on algal diversity. We reveal that algal diversity is higher in the large lakes like Alakol, Balkhash and Shardara as well as in the lakes with low saline fresh water. Comparison of studied floras with inclusion- crossing dendrites statistical generation reveals not only influence of the lake size but also salinity class for total diversity and diversity of diatoms. For total diversity, Chlorophyta and diatoms species richness the floristic core was define the special group of mountain lakes. Cyanobacteria species richness was higher in fresh lakes class salinity 1 , then in the lakes of 2-3 salinity class. We can to conclude in this calculation base that salinity and the size of the lake play the major role for species richness forming process in the Kazakhstan lakes algal flora. Comparative floristic analysis revealed the tendencies in forming process of the Kazakhstan algal diversity, which is under influence of arid climatic factors such as high evaporation and salinity of the lakes increasing.
\end{abstract}

Keywords: algae, lakes, flora, comparative floristic, Kazakhstannt
Volume 3 Issue 4 - 2018

\author{
Jiyenbekov A,' Barinova S, ${ }^{2}$ Bigaliev A,' \\ Nurashov $S,{ }^{3}$ Sametova $E,{ }^{3}$ Fahima $T^{2}$ \\ 'Al- Faraby Kazakh National University, Republic of Kazakhstan \\ ${ }^{2}$ Institute of Evolution, University of Haifa, Israel \\ ${ }^{3}$ Institute of Botany and Phytointroduction, Kazakhstan
}

Correspondence: Barinova S, Institute of Evolution, University of Haifa, Mount Carmel, 199 Abba Khoushi Ave, Haifa 3498838, Israel,Email sophia@evo.haifa.ac.il

Received: July 19, 2017 | Published: August 02, 2018

\section{Introduction}

The Alakol Lake is a unique natural water body with a gradient of salinity in which algal diversity has been never studied before our research. The lake received status Alakol Lake State Natural Reserve from 1998 in the frame of the Convention on Biological Diversity ratified by the Parliament of Kazakhstan in 2004, thus affirming its desire to preserve the unique richness of nature in the country. In the first step of investigation of the new natural reserve monitoring was the identification of the biological diversity. Whereas some aquatic invertebrates were studied accidentally in the Alakol Lake, ${ }^{1}$ the algal diversity study is in initial step because up to current research the information about algal species of the Alakol Lake was absent. As a result of our preliminary study, we revealed 203 algal species (208 with infraspecific taxa) from five taxonomic Division during 2015-2017 sampling period. ${ }^{2}$ This research project is continue our algal floristic study that started in 2000 with support of WWF on the territory of Kazakhstan. ${ }^{3-7}$. So, the Alakol Lake algal flora represent next step of floristic study of water bodies in protected areas of Kazakhstan. In Kazakhstan, the arid and semiarid dry grasslands to deserts are widespread in the upper reaches of Ob River Basin and the Turkestan Desert. ${ }^{8}$ Large highly mineralized lakes Balkhash, Tengiz, Issyk Kul and Karakul, as well as the Aralian and Caspian seas, are confined to this climatic region. ${ }^{9}$ Phytogeographically, this region is situated near the boundary of the Irano- Turanian province and the Boreal province north of it. ${ }^{10} \mathrm{~A}$ large number of lakes in this area are protected on account of their importance for biodiversity conservation. ${ }^{11}$ The aim of present work is to compare algal floristic diversity in the protected lakes of Kazakhstan, including the Alakol Lake with algal floras of other large water bodies such as Balkhash Lake, Kolsay lakes, Shardara, and Sorbulak reservoirs in which algal species list was compiled by us earlier. Statistical instruments will implemented for comparative floristic analysis in purpose to reveal major environmental factors that influenced algal floras forming process in arid region of Eurasia.

\section{Description of study site}

Lake Alakol and the adjacent part of the basin of its catchment area is a protected natural area. The lake is a drainage lake, belongs to the ecoregion 624 (Balkash- Alakul) according to the FEOW classification $^{12}$ and once represented a single water system with Lake Balkhash. It is located at an altitude of $348 \mathrm{~m}$ above sea level on the Balkhash-Alakol lowland, which lies on the border of the Almaty and East Kazakhstan regions, in the eastern part of the BalkhashAlakol depression (Figure 1). The Alakol Lake, as new included site for floristic comparison, was studied in 2015-2017. Figure 1 represent sampling points on the lake in three different areas- Kamyskala, Akshi, and Koktuma. The area of the lake is about 2,696 square kilometers, the water volume 58.56 cubic $\mathrm{km}$, length $104 \mathrm{~km}$, and width about $52 \mathrm{~km}$. Average depth is about $22 \mathrm{~m}$ with $54 \mathrm{~m}$ maximal. The close placed lakes Sasykkol, Uyaly, Zhalanashkol and others, smaller, together with the Alakol Lake are forms the Alakol Lake system. The climate of the coast is sharply continental with a complex wind regime, ice about two month, and water temperature in range $7-25^{\circ} \mathrm{C}$. The waters of the lake are brackish, chloride- sodium and 
chloride- sulfate- sodium, depending on the lake area, averaging about 5.9- $7.8 \mathrm{~g} \mathrm{l}^{-1} .^{1}$ In the waters of Lake Alakol, the high content of fluorine and bromine. ${ }^{13}$

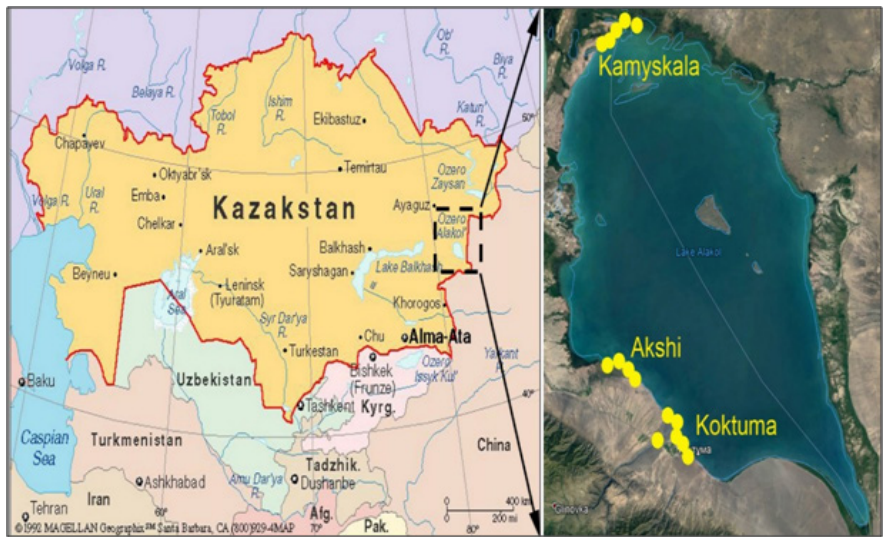

Figure I Sampling points in three areas of the Alakol Lake, Kazakhstan in 20I5-2017.

\section{Material and methods}

Algal communities were studied in altogether 34 lakes, Karasu River mouth near Lake Tuntugur, Jailma Well near Lake Kulykol, and Jarsor Brook near Lake Jarsor (most of them protected, ${ }^{11}$ which are located on the northern Kazakhstan arid area. ${ }^{3-6}$ Into analysis were included the Zerenda protected lake, ${ }^{7}$ the Alakol protected lake, ${ }^{2}$ and algal floras from large water bodies in middle and southern Kazakhstan: Balkhash Lake, Kolsay lakes, Shardara, and Sorbulak reservoirs. ${ }^{14-23}$ The species lists and environmental data for present study comes from mentioned references. GRAPHS and Statistica 12.0 programs were used for comparative floristic and dendrograms and dendrites construction. ${ }^{24}$

\section{Results and discussion}

Environmental and biological variables for the studied lakes in Kazakhstan are presented in Table 1. Can be seen that environmental variables of Kazakhstan's protected areas are varied in large range. Their salinity (correlated with water conductivity) varies from 0.19 to $39.9 \mathrm{~g} \mathrm{NaCl}$ per liter with salinity class from I to IV increasing during the summer dry period. The acidity varies from slightly acid to alkaline, whereas the concentration of nitrates attests to a sufficient trophic base for algal development. At the same time, the saprobity indices varied from 0.76 in Kolsay Sary-Bulak Lake to 2.7 in Aksuat Lake. Table 2 show distribution of algal diversity over taxonomic Divisions for studied lakes. As in Table 1 of environmental variables, the algal species richness is varied in wide range from minimal one species to 203 that is maximal in the Alakol Lake. Richest in the algal floras of the lakes is Diatoms, followed green algae. Total species list that was compiled for 42 studied lakes are represented by 554 taxa of species and infraspecies level. It is very interesting that most of species (about 98\%) was represented by one variation only, usually typical. In Table 2 and the total list of compared floras can be seen that species composition for each flora is very individual, nevertheless wide range of environmental variables. High floras individuality can be result of protection regime in the lakes that help to survive natural algal diversity.

We calculated algal species lists similarity for studied lakes with Sórensen-Chekanovsky indices and on the base of Euclidian distance constructed the tree of similarity (Figure 2) for total species richness in program GRAPHS. So, dendrogram show three different clusters on the $50 \%$ level of similarity. Cluster 1 included three largest lakes floras: the Alakol, Shardara, and Balkhash. Second cluster included richest floras of unpolluted lakes, and the third cluster unites the flora of all other lakes (Table 2).

Table I Biological and environmental variables average data for the lakes in Kazakhstan with the clusters number in total dendrogram and core number in total dendrite

\begin{tabular}{|c|c|c|c|c|c|c|c|c|c|}
\hline Lake & $\begin{array}{l}\text { Conductivit, } \\
\mathrm{mSm} \mathrm{cm}^{-1}\end{array}$ & $\begin{array}{l}\mathrm{NaCl} \\
\mathrm{g} \mathrm{L}^{-1}\end{array}$ & $\begin{array}{l}\text { Class of } \\
\text { salinity }\end{array}$ & pH & $\begin{array}{l}\mathrm{N}-\mathrm{NO}_{3}, \\
\mathrm{mg} \mathrm{L}^{-1}\end{array}$ & $\begin{array}{l}\text { No. of algal } \\
\text { species }\end{array}$ & $\begin{array}{l}\text { Saprobity } \\
\text { index S }\end{array}$ & $\begin{array}{l}\text { Total tree } \\
\text { cluster }\end{array}$ & $\begin{array}{l}\text { Total } \\
\text { dendrite } \\
\text { core }\end{array}$ \\
\hline Aike & 11.73 & 6.79 & III & 7.01 & 3.4 & 19 & 1.98 & 3 & 3 \\
\hline Aksuat & 4.05 & 2.32 & IV & 6.36 & 1.2 & I & 2.7 & 3 & 3 \\
\hline Alpash & 8.72 & 4.92 & IV & 7.05 & 1 & 13 & 1.74 & 3 & 2 \\
\hline Annovskoe & 0.75 & 0.44 & IV & 6.99 & 1.6 & 22 & 1.76 & 4 & I \\
\hline Balykty & 4.33 & 2.43 & IV & 7.84 & 1.1 & 26 & 2.21 & 3 & 3 \\
\hline Batpakkol & 0.37 & 0.21 & IV & 7.29 & 2.3 & 2 & 2 & 3 & 3 \\
\hline Biesoygan & 0.85 & 0.52 & IV & 6.76 & 2.1 & 7 & 2.55 & 4 & 3 \\
\hline Bozshakol & 0.77 & 0.46 & IV & 6.9 & 5.1 & 63 & 2.04 & 4 & 3 \\
\hline Chushkaly & 16.4 & 9.35 & III & 6.94 & I.7 & 18 & 1.97 & 2 & 1 \\
\hline Gr. Kak & 57.3 & 32.7 & II & 6.36 & 2.2 & 6 & 2.11 & 3 & 3 \\
\hline Gr. Karakamys & 1.85 & 1.08 & IV & 6.63 & I & 28 & 1.73 & 3 & 3 \\
\hline Gr. Sankebay & 14.29 & 8.17 & III & 7.4 & 1.6 & 3 & 2.49 & 2 & I \\
\hline Jaltyr & II.47 & 6.52 & III & 6.77 & I & 6 & 1.86 & 4 & 3 \\
\hline Jaman & 0.39 & 0.23 & IV & 7.04 & 1.4 & 57 & 1.94 & 3 & 3 \\
\hline Jarken & 0.86 & 0.49 & IV & 6.74 & 0.9 & 22 & 2 & 3 & 3 \\
\hline
\end{tabular}


Table continued....

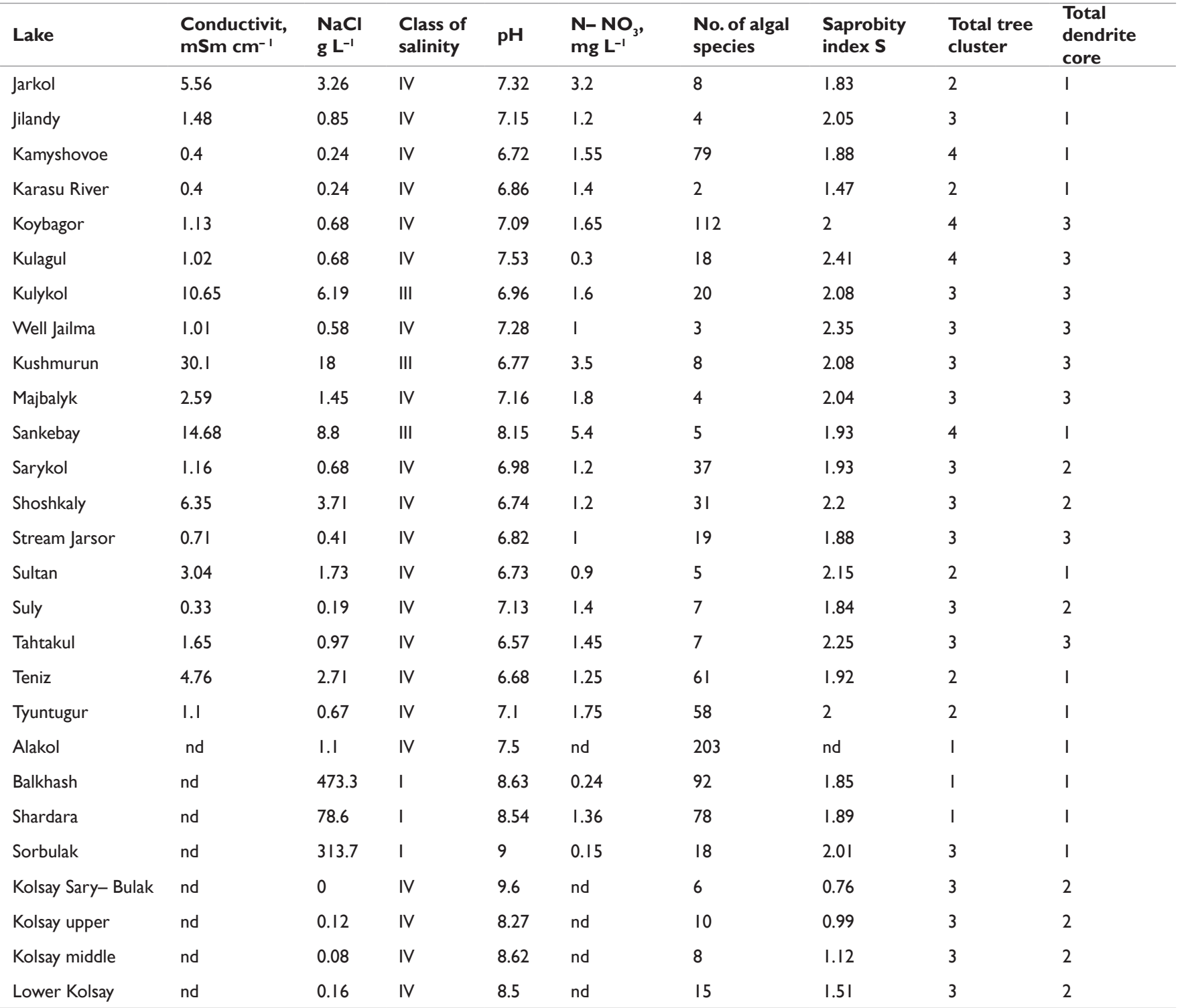

Abbreviation nd - no data

Table 2 Distribution of species richness in taxonomic division over studied lakes of Kazakhstan

\begin{tabular}{|c|c|c|c|c|c|c|c|c|c|c|c|c|}
\hline Lake & $\begin{array}{l}\text { Cyano- } \\
\text { bacteria }\end{array}$ & $\begin{array}{l}\text { Bacilla- } \\
\text { riophyta }\end{array}$ & $\begin{array}{l}\text { Cryp- } \\
\text { tophyta }\end{array}$ & $\begin{array}{l}\text { Eugle- } \\
\text { nozoa }\end{array}$ & Miozoa & $\begin{array}{l}\text { Chry- } \\
\text { sophyta }\end{array}$ & $\begin{array}{l}\text { Chloro- } \\
\text { phyta }\end{array}$ & $\begin{array}{l}\text { Charo- } \\
\text { phyta }\end{array}$ & $\begin{array}{l}\text { Total } \\
\text { number } \\
\text { of species }\end{array}$ & $\begin{array}{l}\text { Bacilla- } \\
\text { riophyta } \\
\text { cluster }\end{array}$ & $\begin{array}{l}\text { Chloro- } \\
\text { phyta } \\
\text { cluster }\end{array}$ & $\begin{array}{l}\text { Cyano- } \\
\text { bacteria } \\
\text { cluster }\end{array}$ \\
\hline Aike & 7 & I & I & - & - & - & 9 & - & 18 & 2 & I & 2 \\
\hline Aksuat & - & I & - & - & - & - & - & - & I & 2 & 2 & 3 \\
\hline Alpash & - & 10 & - & 1 & - & - & I & - & 12 & 2 & 2 & 3 \\
\hline Annovskoe & 2 & 5 & - & 2 & - & - & 7 & 4 & 20 & 2 & 2 & 3 \\
\hline Balykty & - & 4 & - & - & - & - & - & - & 4 & 2 & 2 & 3 \\
\hline Batpakkol & I & I & - & - & - & - & - & - & 2 & 2 & 2 & 3 \\
\hline Biesoygan & - & 21 & - & - & - & - & 3 & I & 25 & 3 & 2 & 3 \\
\hline Bozshakol & I & 7 & - & I & - & - & 3 & - & 12 & 3 & 2 & 3 \\
\hline
\end{tabular}


Table continued....

\begin{tabular}{|c|c|c|c|c|c|c|c|c|c|c|c|c|}
\hline Lake & $\begin{array}{l}\text { Cyano- } \\
\text { bacteria }\end{array}$ & $\begin{array}{l}\text { Bacilla- } \\
\text { riophyta }\end{array}$ & $\begin{array}{l}\text { Cryp- } \\
\text { tophyta }\end{array}$ & $\begin{array}{l}\text { Eugle- } \\
\text { nozoa }\end{array}$ & Miozoa & $\begin{array}{l}\text { Chry- } \\
\text { sophyta }\end{array}$ & $\begin{array}{l}\text { Chloro- } \\
\text { phyta }\end{array}$ & $\begin{array}{l}\text { Charo- } \\
\text { phyta }\end{array}$ & $\begin{array}{l}\text { Total } \\
\text { number } \\
\text { of species }\end{array}$ & $\begin{array}{l}\text { Bacilla- } \\
\text { riophyta } \\
\text { cluster }\end{array}$ & $\begin{array}{l}\text { Chloro- } \\
\text { phyta } \\
\text { cluster }\end{array}$ & $\begin{array}{l}\text { Cyano- } \\
\text { bacteria } \\
\text { cluster }\end{array}$ \\
\hline Chushkaly & 7 & 29 & - & I & - & - & 15 & I & 53 & I & I & 2 \\
\hline Gr Kak & 4 & 2 & - & - & - & - & - & - & 6 & 2 & 2 & 3 \\
\hline Gr Karakamys & - & 4 & - & - & - & - & 2 & - & 6 & 2 & 2 & 3 \\
\hline Gr Sankebay & 4 & 29 & - & 3 & - & - & 17 & 2 & 55 & I & I & 2 \\
\hline Jaltyr & 2 & II & I & I & - & 2 & 7 & 2 & 26 & 3 & 2 & 3 \\
\hline Jaman & - & 2 & - & - & - & - & - & - & 2 & 2 & 2 & 3 \\
\hline Jarken & - & 3 & - & I & - & - & - & - & 4 & 2 & 2 & 3 \\
\hline Jarkol & 7 & 40 & I & 2 & - & - & 16 & 10 & 76 & I & 2 & 2 \\
\hline Jilandy & I & 4 & - & - & - & - & I & - & 6 & 2 & 2 & 3 \\
\hline Kamyshovoe & 2 & 18 & - & - & - & 2 & 5 & I & 28 & 3 & 2 & 3 \\
\hline Karasu River & 10 & 45 & I & 6 & I & - & 36 & 4 & 103 & I & I & I \\
\hline Koybagor & 6 & 6 & I & - & - & - & 4 & - & 17 & 3 & 2 & 2 \\
\hline Kulagul & 1 & 12 & I & - & - & I & 3 & I & 19 & 2 & 2 & 3 \\
\hline Kulykol & - & 2 & - & - & - & - & I & - & 3 & 2 & 2 & 3 \\
\hline Well Jailma & 1 & 7 & - & - & - & - & - & - & 8 & 2 & 2 & 3 \\
\hline Kushmurun & - & 3 & - & I & - & - & - & - & 4 & 2 & 2 & 3 \\
\hline Majbalyk & - & 5 & - & - & - & - & - & - & 5 & 2 & 2 & 3 \\
\hline Sankebay & 2 & 13 & I & 2 & - & - & 13 & 4 & 35 & 3 & I & 3 \\
\hline Sarykol & 2 & I & - & - & - & - & I & I & 5 & 2 & 2 & 3 \\
\hline Shoshkaly & - & 6 & - & - & - & - & I & - & 7 & 2 & 2 & 3 \\
\hline Stream Jarsor & I & 1 & I & - & - & - & - & - & 3 & 2 & 2 & 3 \\
\hline Sultan & 7 & 19 & - & I & - & I & 9 & 2 & 39 & 3 & I & 2 \\
\hline Suly & - & 2 & - & - & - & - & 2 & - & 4 & 2 & 2 & 3 \\
\hline Tahtakol & - & 2 & I & I & - & - & 2 & - & 6 & 2 & 2 & 3 \\
\hline Teniz & 7 & 29 & - & - & - & I & 13 & 4 & 54 & I & I & I \\
\hline Tyuntugur & 3 & 35 & - & 3 & - & - & 15 & 2 & 58 & I & I & I \\
\hline Alakol & 20 & $|4|$ & - & 6 & - & - & 16 & 20 & 203 & I & I & I \\
\hline Balkhash & 21 & 27 & - & 4 & 3 & 2 & 29 & 4 & 90 & 3 & I & I \\
\hline Shardara & 8 & 16 & - & - & 8 & 3 & 41 & 2 & 78 & 3 & I & 2 \\
\hline Sorbulak & 2 & 6 & - & - & 3 & - & 5 & 2 & 18 & 2 & 2 & 3 \\
\hline $\begin{array}{l}\text { Kolsay Sary- } \\
\text { Bulak }\end{array}$ & - & I & - & - & - & - & 3 & I & 5 & 2 & 2 & 3 \\
\hline Upper Kolsay & - & 8 & - & - & - & - & 2 & - & 10 & 3 & 2 & 3 \\
\hline Middle Kolsay & - & 9 & - & - & - & - & - & - & 9 & 3 & 2 & 3 \\
\hline Lower Kolsay & 3 & 7 & - & 2 & - & - & 4 & - & 16 & 3 & 2 & 3 \\
\hline
\end{tabular}




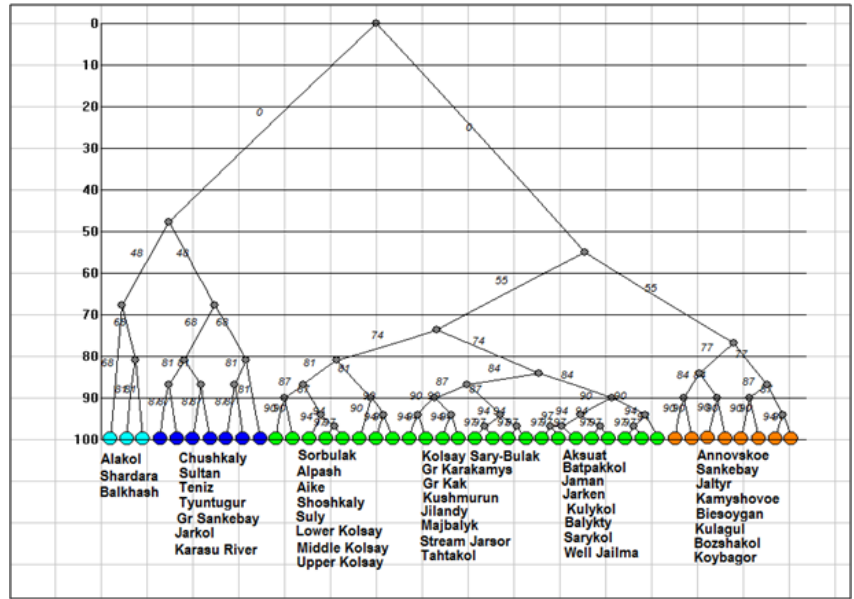

Figure 2 Dendrogram of similarity for the Kazakhstan lakes algal communities. Clusters marked by different color.

Dendrite of inclusion- crossing for total species richness (Figure 3) demonstrated four floristic cores of algal diversity in the protected lakes of Kazakhstan. The first core with Chushkaly Lake is largest and unites richest floras of largest lakes, including of the Alakol Lake. Cores 2 represent the group of Kolsay high mountain lakes. Shoshkaly core unites the poorest flora. All other diverse floras are combined with Bozshakol Lake core. Special interest can represent the analysis of floristic similarity for the different taxonomic Division. Therefore, Figure $4 \&$ Table 2 represents similarity of diatom floras of studied lakes. Three clusters are divided the lakes floras on the $50 \%$ of similarity. The first cluster (blue) included seven richest floras: the Alakol, Chushkaly, Tuntugur, Teniz, Gr. Sankebay, Jarkol, and the Karasu River mouth in which species number varied between 141 and 29. Second cluster (green) represent most part of studied floras, which have similarity of species list more than $73 \%$ and poorest diatom floras. Third cluster included twelve floras with similarity of $64 \%$ such as Shardara, Balkhash, Kolsay lakes and other in which have middle diatom species contain between 11 and 27. So, diatom list of similarity is repeating the tendency which has been revealed for total floras and demonstrated relatedness of similarity percent with species richness in algal floras. Dendrite for Bacillariophyta is divided algal floras for three different cores with center in flora of Koybagor (orange), Gr. Sankebay (blue), and Kolsay group of lakes. Interesting that the Alakol diatom flora is very individual and have low similarity nevertheless included to the core of Gr. Sankebay group of lakes (Figure 5). Cores of diatom floras are similar to total species richness analysis. Comparison of the Chlorophyta floras show (Figure 6) (Table 2) two major clusters on the similarity level of $50 \%$, the first of them can be divided into two sub clusters on the similarity about $56 \%$. So, first sub cluster (blue) included only four floras of the lakes Alakol, Balkhash, Shardara, and Karasu River mouth. Second sub cluster (light blue) combine twelve lakes with similarity of its green algal floras on the level about $72 \%$. All 16 floras of both sub clusters are most species rich by green algae. Cluster 2 included all other lakes floras in which green algae are low presented. Figure 7 represent the calculation for an inclusion- crossing dendrite of Chlorophyta floras of studied lakes. Here can be seen that Akalol Lake flora (blue) have no similarity with most of compared floras because have small no of the Chlorophyta species. So, only three cores can be defined in the dendrite: core of Bozshakol with low green species richness, core of
Alpash with minimal species number but similar to this group floras, and core of Chushkaly lake that included all other floras species. Altogether, the similarity of green algae calculation demonstrated in first low correlation with species richness and high individuality of green algal floras of studied lakes. Only one environmental variable can be mentioned as related to green algae floras similarity- the neutral or low alkaline water $\mathrm{pH}$.

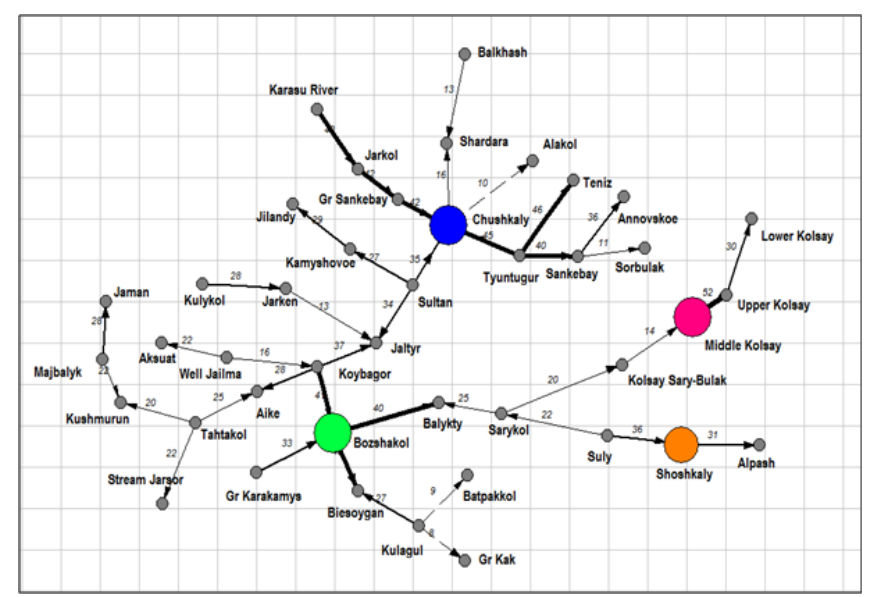

Figure 3 An inclusion- crossing dendrite for floras of the Kazakhstan lakes algal communities. Floristic cores marked by different color, arrows marked inclusion direction.

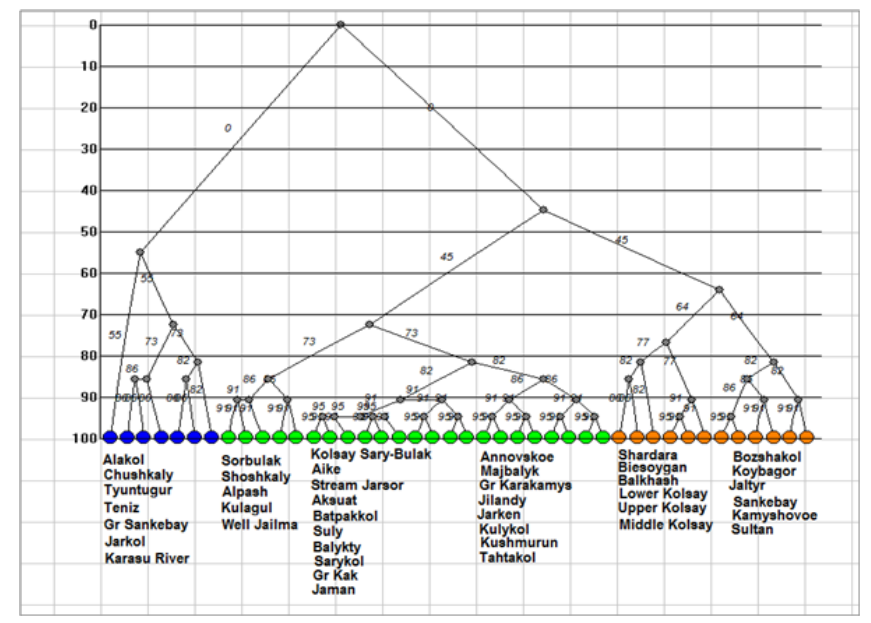

Figure 4 Dendrogram of similarity for Bacillariophyta floras of the Kazakhstan lakes. Clusters marked by different color.

A special interest represent of cyanobacteria floras similarity analysis. Tree of similarity on the Figure 8 (Table 2) help us to revealed three different clusters on the similarity level about $60 \%$. Cluster 1 included cyanobacteria from the lakes Alakol, Shardara, Karasu River mouth, Teniz, and Tyuntugur (blue). Cluster 1 floras are formed in wide range of salinity lakes $\left(0.67-78.6 \mathrm{~g} \mathrm{~L}^{-1}\right)$ and $\mathrm{pH}(6.8-$ 8.54 ) but low organic polluted and waters. Next seven cyanobacteria floras are unified into cluster 2 with similarity level about $64 \%$. There are floras of the Balkhash, Sultan, Chushkaly, Aike, Gr. Sankebay, Jarkol, and Koybagor lakes in which also has different salinity of classes I- IV and water $\mathrm{pH}$ but slightly more organically polluted than lakes of cluster 1 . So, we cannot see clear differences between clusters 
of tree. Similarity dendrite for cyanobacteria floras (Figure 9) is divided all species richness into two cores. Core 1 is formed near the lake Koybagor with Annovskoye, Sankebay and Well Jailma. These floras are characterized by middle species richness of cyanobacteria but total species richness is rather rich. We do not find some specific parameters for the lakes of this core. Core two combine all other cyanobacteria floras but the environment of this core lakes cannot be defined because in one set of floras the cyanobacterial diversity is low and in other is absent.



Figure 5 An inclusion- crossing dendrite for Bacillariophyta floras of the Kazakhstan lakes. Floristic cores marked by different color, arrows marked inclusion direction.

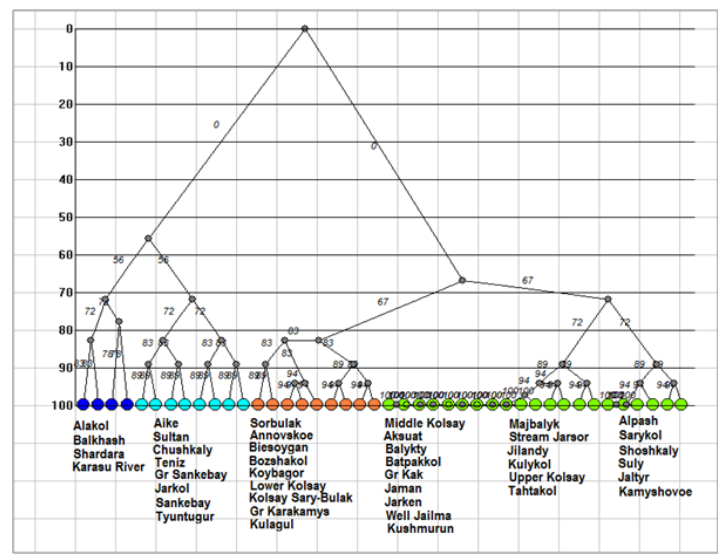

Figure 6 Dendrogram of similarity for Chlorophyta floras of the Kazakhstan lakes. Clusters marked by different color.

Earlier we found strong correlation between species richness and water salinity class for the Northern Kazakhstan lakes. ${ }^{3-6}$ Comparative floristic tree of the Kostanay district lakes floras has been divided for three clusters and confirms influence of salinity to species richness. More of them, when we included into calculation the lakes of wide salinity spectrum from Israel, we received the same distribution with strong relatedness of species richness and salinity. ${ }^{5}$ Therefore, we can assume that our calculation for all known Kazakhstan lakes floras can help us to classify studied lakes as salinity classes for each cluster in dendrogram Figure 2. Table 1 show that for total species richness this is not so, because the chlorides concentration in the Alakol Lake is smallest than in the lakes from same cluster Balkhash and Shardara. ${ }^{25}$ This correlation is better works for diatoms tree (Table 1,2) (Figure 4) but not for Cyanobacteria (Figure 8). The Chlorophyta species richness is highest in the freshwater lakes. Therefore, it is better indicators of salinity (Figure 6) but some influence of the lake size can be seen here also. It let us to assume that total species richness is increase with the lake size increasing but diatom and chlorophyte species richness are related to chlorides concentration more than lake volume. In respect of cyanobacteria diversity can be assumed that its species richness is increase in more freshwater lakes.

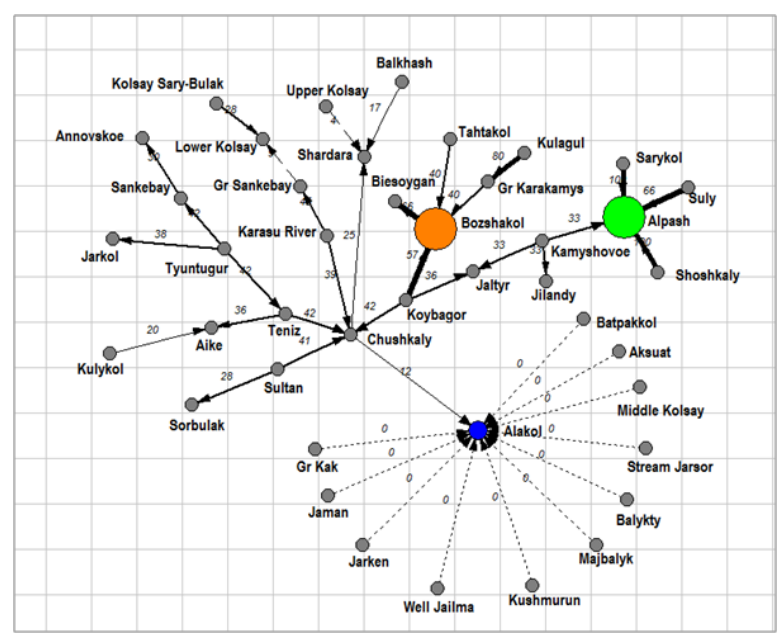

Figure 7 An inclusion- crossing dendrite for Chlorophyta floras of the Kazakhstan lakes. Floristic cores marked by different color, arrows marked inclusion direction.

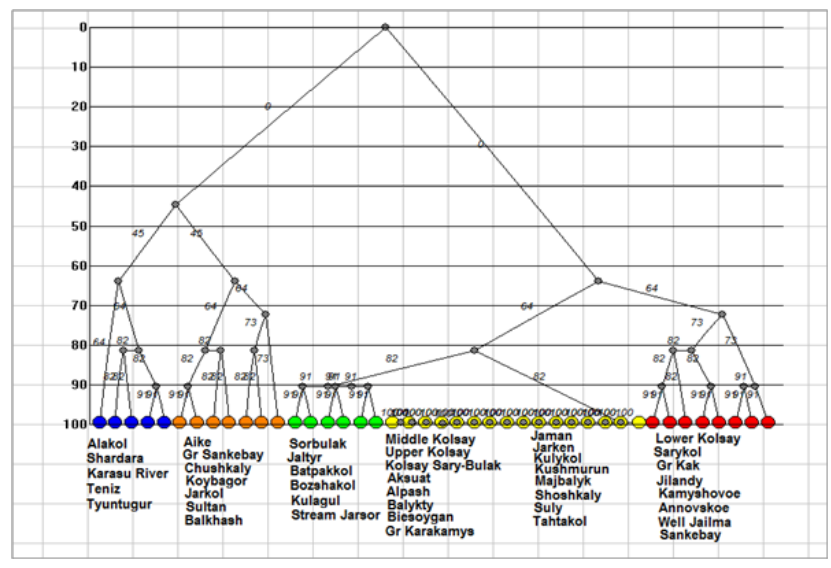

Figure 8 Dendrogram of similarity for Cyanobacteria floras of the Kazakhstan lakes. Clusters marked by different color.

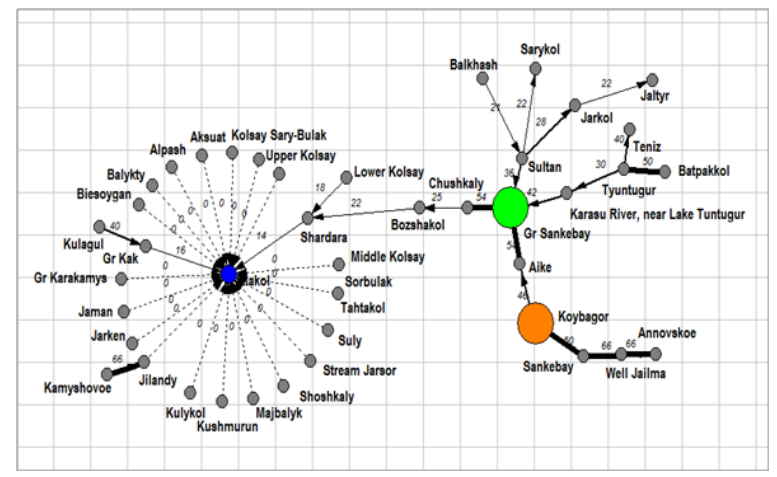

Figure 9 An inclusion- crossing dendrite for Cyanobacteria floras of the Kazakhstan lakes. Floristic cores marked by different color, arrows marked inclusion direction. 


\section{Conclusion}

Total species richness comparative floristic analysis demonstrated importance of the water body size, which correlated with species number in the lake floras. It can better see in the diatom floras comparison cluster tree of which is related to the lake salinity class also. Cyanobacteria and Chlorophyta species richness are highest in the freshwater lakes as can be seen in its similarity tree. Therefore, it is better indicators of salinity but some influence of the lake size can be seen here also. So, total species richness is increase with the lake size increasing but diatom and chlorophyte species richness are related to chlorides concentration more than lake size. The Cyanobacteria tree demonstrated increasing of species richness in freshwater lakes. From other hand, we found that inclusion- crossing dendrites for total flora of studied lakes as well as for different taxonomic Division can be used for the algal floristic forming process in Kazakhstan. Total algal floras analysis with revealing of floristic cores show two major cores in which is concentrated of species diversity. One of them is related to freshwater and second to special high mountain environment. The same distribution is demonstrated by diatom and chlorophyte floras dendrites. However, cyanobacteria dendrite revealed correlation of core members with the salinity Class of the lake. Therefore, we can to conclude that salinity and the size of the lake play the major role for species richness in the Kazakhstan lakes flora forming process. More of them, comparative floristic analysis revealed the tendencies in forming of the Kazakhstan diversity that is influenced by arid climatic factors such as high evaporation and salinity of the lakes increasing.

\section{Acknowledgements}

This work was partly supported by Committee of Science, Ministry of Education and Science, Republic of Kazakhstan as well as by the Israeli Ministry of Aliyah and Integration.

\section{Conflict of interest}

The author declares there is no conflict of interest.

\section{References}

1. Krupa EG, Amirgalieva NA, Lopareva T Ya. Zooplankton of Lake Alakol and its distribution depending on mineralization and chemical composition of water. Bulletin of the Kazakh National University Al-Farabi, biological series, Almaty. 2010;1(43):96-100.

2. Jiyenbekov A, Barinova S, Bigaliev A. The first evidence about the algae of the protected Alakol Lake (Kazakhstan) and their floral analysis. Bulletin of Moscow society of naturalists, biological series. Russia; 2018.

3. Barinova SS, Karlsen AG, Solovieva AA. Sustainable assessment of some water ecosystems of Kostanai Oblast and west part of North-Kazakhstan Oblast on the hydrochemical and hydrobiological dates. In: Bragina TM, Bragin EA, editors. The most important wetlands of North Kazakhstan (Kostsnai Oblast and west part of North-Kazakhstan Oblast). Moscow: World Wildlife Found Press, 2002;39-43.

4. Barinova SS, Bragina TM, Nevo E. Influence of major environmental factors on the diversity of algae in the arid ecosystems. Proceedings of International Symposium. Biological Diversity of Asian Steppes, Kostanay, Kazakhstan. 2007;150-153.

5. Barinova SS, Bragina TM, Nevo E. Algal species diversity of arid region lakes in Kazakhstan and Israel. Community Ecology. 2009;10(1):7-16.

6. Barinova SS, Nevo E, Bragina TM. Ecological assessment of wetland ecosystems of northern Kazakhstan on the basis of hydrochemistry and algal biodiversity. Acta Botanica Croatica. 2011;70(2):215-244.

7. Barinova SS, Romanov RE. Towards an inventory of algal diversity of the Zerenda Lake, Northern Kazakhstan. In: Abil EA, Bragina TM, editors.
Biological Diversity of Asian Steppe. Proceedings of the III International Scientific Conference Kostanay: KSPI, 2017;139-144.

8. The Natural Regions of Northern Kazakhstan. St-Peterburg: Academic Press, Moscow, Russia; 1960.

9. Hammer UT. Saline lake ecosystems of the world. Dordrecht, Boston, Lancaster: Dr W. Junk Publishers. 1986. p. 616.

10. Takhtajan A. The floristic regions of the world. Leningrad: Nauka Press, Russia; 1978.

11. Bragina TM, Bragin EA. The most important wetlands of North Kazakhstan (Kostanai Oblast and west part of North-Kazakhstan Oblast). Moscow: Russian Univ. Press. 2002.

12. Freshwater ecoregions of the world (FEOW). 2018.

13. Berezovikov N. Alakol State Nature Reserve. In: Yaschenko RV, editor. Reserves of Central Asia and Kazakhstan. Protected natural areas of Central Asia and Kazakhstan. Almaty: Tethys. 2006;(1):12-13.

14. Krupa EG, Barinova SS, Romanova SM. Et al. Hydrobiological assessment of the high mountain Kolsay lakes (Kungey Alatau, Southeastern Kazakhstan) ecosystems in climatic gradient. British Journal of Environment and Climate Change. 2016;6(4):259-278.

15. Krupa EG, Barinova SS, Tsoy VN. Formation of phytoplankton of Lake Balkhash (Kazakhstan) under the influence of major regional-climatic factors. Advances in Biology and Earth Sciences. 2017a;2(2):204-213.

16. Krupa EG, Barinova SS, Amirgaliyev NA, et al. Statistical approach to estimate the anthropogenic sources of potentially toxic elements on the Shardara Reservoir (Kazakhstan). MOJ Ecology \& Environmental Sciences. 2017b;2(1):1-8.

17. Krupa EG, Barinova SS, Tsoy VN. Spatial analysis of hydrochemical and toxicological variables of the Balkhash Lake, Kazakhstan. Research Journal of Pharmaceutical, Biological and Chemical Sciences. 2017c;8(3):1827-1839.

18. Krupa EG, Barinova SS, Isbekov KB. Influence of chemical water composition on spatial distribution of phytoplankton in the Balkhash Lake (Kazakhstan). Research Journal of Pharmaceutical, Biological and Chemical Sciences. 2017d;8(5):396-411.

19. Krupa E, Barinova S, Ponamareva L, et al. Statistical mapping and 3-D surface plots in phytoplankton analysis of the Balkhash Lake (Kazakhstan). Transylv. Rev. Syst. Ecol. Res. "The Wetlands Diversity". 2018;20(1):1-16.

20. Barinova S, Krupa E. Bioindication of Ecological State and Water Quality by Phytoplankton in the Shardara Reservoir, Kazakhstan. Environment and Ecology Research. 2017;5(2):73-92.

21. Barinova S, Krupa E, Romanova S. The role of planktonic algae in the ecological assessment of storage-reservoirs of the Ili-Balkhash basin. Transylvanian Review of Systematical and Ecological Research, The Wetlands Diversity. 2018a;20(2):1-14.

22. Barinova S, Krupa E, Tsoy V. The application of phytoplankton in ecological assessment of the Balkhash Lake (Kazakhstan). Applied Ecology and Environmental Research. 2018b;16(3):2089-2111.

23. Barinova S, Krupa E, Kadyrova U. Spatial dynamics of species richness of phytoplankton of Lake Balkhash (Kazakhstan) in the gradient of abiotic factors. Transylvanian Review of Systematical and Ecological Research, The Wetlands Diversity. 2017;19(2):1-18.

24. Novakovsky AB. Abilities and base principles of program module "GRAPHS". Scientific Reports of Komi Scientific Center, Ural Division of the Russian Academy of Sciences. 2004;27:1-28.

25. Barinova S, Krupa E. Critical environmental factors for photosynthetic organisms of the Shardara Reservoir, Kazakhstan. Bulletin of Advanced Scientific Research. 2016;2(5):17-27. 